Joanna Szydełko

ORCID: 0000-0003-0669-1271

Pedagogical University of Kraków

\title{
The quest for a successful book-to-series adaptation in the times of SVOD - using the examples of The Handmaid's Tale and Alias Grace by Margaret Atwood
}

Abstract: A fascinating factor of so-called mass culture is the ability to adapt to society and its needs. The same pattern seems to be followed by the film industry, as it has been influenced by other branches of entertainment, television included. These are SVODs (Streaming Video on Demand platforms), which offer a growing number of screen adaptations of literary works. The following paper aims to analyse some criteria upon which book-to-series adaptations might be regarded as successful, using examples from The Handmaid's Tale and Alias Grace. Produced respectively by Hulu and CBC, both based on books by the Canadian female writer Margaret Atwood, the analysed shows confirm that the audience is more inclined to watch (and read) an intertextual production that often reflects and comments on contemporary political and social reality.

Keywords: adaptation studies, SVOD industry, intertextuality, Canadian female writing, speculative fiction

Book adaptation is a unique subject, as it seems to belong half-way to the worlds of both film and literature. Nevertheless, intersections between the two maintain a rather troublesome position in academic discussion. Even though the idea of transmitting a literary text onto the screen is not new, it has been regarded as "too literary for film studies and too film-based for literary studies". ${ }^{1}$ With this being noticed, one should ask whether this liminal place, occupied by bookto-film and book-to-series adaptations, should be re-analysed from a different, broader perspective. The question of what a successful adaptation is remains as a further interest of this analysis.

The development of technology has affected social and cultural trends and patterns in the film industry. It has been changing rapidly, being constantly influenced

${ }^{1}$ D. Cartmell, I. Whelehan, The Cambridge Companion to Literature on Screen, Cambridge 2007, p. 14. 
by other branches of the entertainment industry, television included. When some might have believed in the imminent demise of television, it seems that it has not yet reached its limits. This medium is widely and willingly chosen by modern viewers in its new and convenient form, owing everything to the Internet. A growing number of on-demand Internet streaming media providers ${ }^{2}$ and their productions based on literature works might in some way serve as a bridge, bringing us to the necessity of re-interpreting the definition of adaptation. To do so, one should regard both the verb and noun form of the term. To adapt means the same as "to make fit (as for a new use) often by modification", ${ }^{3}$ whereas adaptation may be seen as

1. a composition rewritten into a new form

2. adjustment to environmental conditions: such as

a: adjustment of a sense organ to the intensity or quality of stimulation

b: modification of an organism or its parts that makes it more fit for existence under the conditions of its environment. ${ }^{4}$

Given the above, one must look at literature being a composition that is ready to have its form readjusted. In this regard, reception of literature in its new, adapted form is possible due to the fact of it "being caught up in the ongoing whirl of intertextual transformation, of texts generating other texts in an endless process of recycling, transformation, and transmutation, with no clear point of origin". ${ }^{5}$ Robert Stam therefore notes that altering a literary text into a different form is an active process. Books are adapted to films and TV series and so they become somewhat revived products of intertextuality. The novelty is, however, that in the face of SVOD, the whole process of transformation is much more dynamic. Consequently, both book-to-film and book-to-series adaptations face several issues when being analysed. For many years, this discussion has been rooted in adherence to the adapted text, be it a film or television series script. The quest for fidelity lays in an inevitable comparison between a literary prototype and its onscreen product. The issue of reliability to the original serves as a certain standard that may be applied when judging any book adaptation.

Thomas Van Parys suggests that it was in the centre of adaptation studies before the 1990s. He points out that there are two aspects to be noted when discussing the origin of discussion on fidelity:

On the one hand, the status of literature as a more respectable art from cinema, and, on the other hand, the misapprehension that there is such a thing as a stable original text which dominates every other possible incarnation. ${ }^{6}$

2 These will be later referred to as SVOD - Subscription Video on Demand.

3 https://www.merriam-webster.com/dictionary/adapt (accessed: 5.10.2019).

${ }^{4} \mathrm{https}: / /$ www.merriam-webster.com/dictionary/adaptation (accessed: 5.10.2019).

${ }^{5}$ R. Stam, Film Theory. An Introduction, Oxford 2002, pp. 209-210.

${ }^{6}$ T. Van Parys, "Against fidelity: Contemporary adaptation studies and the example of novelisation”, [in:] Adaptation Theories, ed. J. Saint Jacques, Maastricht 2011, p. 418. 
There are a few problems that one should consider at this point. Firstly, following Thomas Leich's suggestion, ${ }^{7}$ the original text needs to be regarded as if possessing more value when confronted with its onscreen adaptation and only then the discussion on fidelity may be seen to be well-based. Secondly, watching the film or TV series adaptation is, in many cases, based on remembering the novel. That memory can come from either the actual reading experience or can derive from a generally present cultural awareness (which often applies to those works considered as 'classics of literature'). In the process of adapting a book, thanks to intertextuality as well as the ability to reread it, the memory may be consumed and stimulated. The successful adaptation is therefore one that makes it possible to replace common conception of the original, and calls for challenging the issue of fidelity. More than that, with a filmic representation of a literary prototype, the audience is expected or even required to watch with an open mind, so as not to judge the version unfavourably in comparison to the source material.

Now, following poststructuralist theory, this encompasses deconstruction of the novel in a sense of binary opposition; literature and cinema, high and mass culture, original and copy. It is quite clear that the text adapted for filming purposes may vary from the original literary work. Consequently, this urges active, conscious or simply curious readers to either look at the original text for the first time or to look at an adaptation from a different angle; which applies to those already familiar with its literary prototype. A further exploration of a literary text after watching a film or series based on it gives us a possibility to 'watch a book made into a motion picture' from an artistic perspective and therefore, we as the audience, become a valid part of that creation. As both readers and viewers, we should feel entitled to discuss various aspects of adaptation, whether it applies to its credibility, fidelity or artistry. Even so, Christa Albrecht-Crane and Dennis R. Cutchins argue for

a revised approach to adaptation studies that takes into account the ways in which different media contained structures and constraints unique to a particular medium, while recognizing that these differences remain indeterminate and flexible relative to surrounding environments. ${ }^{8}$

In this regard, book-to-series adaptations in the era of SVOD remain important sources of artistic creativity and value. It may be so due to the ability of their authors to respond to the needs and demands of the audience. This viewer-dependant situation very often corresponds with an acceleration in the mass production of blockbusters seen as successful adaptations, which, as a result, have become a fundamental part of the advancement of new media. Along with that, the common availability of Internet streaming websites should be mentioned. This remarkable cultural phenomenon is reflected in one of the SVOD tycoons, Netflix,

7 T. Leich, Film Adaptation and its Discontents: From Gone with the Wind to The Passion of the Christ, Baltimore 2007, p. 20.

${ }^{8}$ C. Albrecht-Crane, D.R. Cutchins, Adaptation studies: new approaches, Madison, NJ 2010, p. 21 . 
whose number of paid subscriptions reached 150 million as of July $2019 .{ }^{9}$ It is beyond any doubt that the largest proportion of subscribers include the generation of "digital natives", for whom SVOD has become a vital source of entertainment. One can choose from an endless list of films, series and entertainment programmes from different genres. It is not only an enjoyable pastime milieu for many viewers, but also seems to be a medium of influencing them socially and culturally. This phenomenon can be observed in book-to-series adaptations; among the myriad of shows the platform offers, there is a considerable number of screen adaptations of literary works. In 2018, Netflix started to purchase around 50 literary projects to be later adapted into feature films or series. ${ }^{10}$ Undeniably, such interest is supported by turning best-selling books into films which, in an era of increased social media activity, may help the television and cinema industries grow in numbers of viewers, regardless of the national identity of the producers. Consequently, we may observe a rebirth of a cultural exchange on a globally digital scale.

Such quick expansion and fertility of SVOD cast doubt on the quality standards applied to their productions. Claiming that the problem lies in having rather a business-minded than art-like approach to book-to-series adaptations may therefore lead to controversy and debate over the creative value of such productions. From the economic point of view, the adapted texts must attract the attention of the largest group of viewers possible. Hence the ultimate need of SVOD creators is to convey their interpretation of a certain book in an entertaining way, but more importantly, they should respond to socio-cultural changes and shifts. By modifying a literary prototype, adapters bring a new analytical perspective to bear. Respectively, one must not forget that book-to-film adaptation serves not only as a layer to discuss the matter of the motion picture itself but also gives an opportunity to take another look at the book. Offering what may be a new life to a literary text may be seen as an added value contributing to the overall success of a book-to-series adaptation.

Another factor contributing to gaining a possibly broader audience (and therefore being recognised as successful) is the softening of the geographical boundaries that SVOD enables. Easy access to various streaming websites worldwide facilitates cultural exchange and awareness of the omnipresence of its trends and patterns. There is an overlapping network of deciding factors of how the authorship may prevail in adaptation of fiction, and the issue of an author's gender is one of them. One may ask whether in the times of ubiquitous online film streaming platforms, viewers are still affected by authorship or if there are other reasons for which a certain adaptation turns out to be a successful one. Moreover, what deter-

${ }^{9} \mathrm{https}: / /$ www.statista.com/chart/10311/netflix-subscriptions-usa-international/ (accessed: 30.08.2019).

$10 \mathrm{https} / /$ www.thebookseller.com/news/netflix-buys-50-literary-projects-last-year-988981 (accessed: 30.08.2019). 
mines the choice of the audience? Does it change because of its age, mass culture awareness or simply popularity of the content they decide to "stream on demand"?

Somehow, all the above-mentioned aspects, are interestingly relative with regards to intersections between Canadian female literature and its film adaptations. Geographic boundaries, however, do not seem to cause as many issues regarding popularity of certain films and series of Canadian origin. The reason for that is most likely the availability of video content, in an industry monopolised by SVOD. An issue worth focusing on is most definitely the growing popularity of female fiction adapted on the silver screen. Margaret Atwood's fiction may stand as a perfect example of the two aspects mentioned: geographical boundaries as well as authorship. One of her most significant achievements, both commercially and critically, is a book published as early as 1985 - The Handmaid's Tale, which has remained a global phenomenon ever since. For instance, it was listed number 37 in the "100 Most Frequently Challenged Books 1990-1999" by The American Library Association. ${ }^{11}$ The Canadian Encyclopaedia claims that over eight million copies in English have been sold; according to Amazon Data, The Handmaid's Tale was the most-read book of 2017. ${ }^{12}$

The popularity of Atwood's novel is reflected in the fact of it having been adapted a number of times: as a film (1990); as radio drama adaptations (firstly in 2000, produced by BBC Radio 4 and later in 2002, produced by Canadian CBC Radio); stage adaptations in 1989 in theatre and opera performances in 2000 (Copenhagen), 2003 (English National Opera, London), in season 2004-2005 in the Canadian Opera Company and, in 2019 in the Boston Lyric Opera; as a ballet adaptation produced by The Royal Winnipeg Ballet in 2013. In April 2017, the streaming service Hulu launched the first season of The Handmaid's Tale as an American dystopian drama web television series, and this turned out to be a great success. Its popularity and excellent artistic execution of a literary prototype has granted its creators several awards (winning eight Primetime Emmy Awards in 2017), but what is currently more important is that it received (and still receives) a large number of positive fan reviews worldwide. The excessive popularity of Hulu's production is reflected in the growing number of viewers who become readers. Is it just a coincidence that the series concept, as well as its plot, happened to be very up-to-date with the political and social tensions around the then-popular \#MeToo movement? Both Donald Trump's election and then turning Atwood's novel into a series is reflected in the growth of the book's sales. When interviewed by an NPR journalist, Atwood's publicist noted that the book has been "selling strongly for months", and that sales rose 60 percent in 2016 while "since the election, it's been a 200 percent increase in sales". ${ }^{13}$ The same tendency was observed

${ }^{11} \mathrm{http}: / /$ www.ala.org/advocacy/bbooks/100-most-frequently-challenged-books-1990\%E2\% 80\%931999 (accessed: 18.10.2019).

$12 \mathrm{https} / / /$ time.com/5059023/most-read-books-2017-amazon/ (accessed: 18.10.2019).

$13 \mathrm{https} / / / \mathrm{www}$.theverge.com/2017/2/11/14586382/sales-margaret-atwoods-handmaids-talesoared-donald- trump (accessed: 20.10.2019). 
by Charlotte Knight, editor at Vintage Classics, which publishes The Handmaid's Tale in the UK, and she told The Guardian's interviewer that:

[a]t the advent of the Trump presidency we saw an extra boost in sales, as it was one of a handful of enduring and brilliant dystopias that readers were turning to at a time of political uncertainty. We were delighted to see that the recent TV adaptation had provided an extra fillip. ${ }^{14}$

The online service Booknet Canada analysed the data connected to the book's sales increase of $82 \%$ a week before and after launching the first episode of The Handmaid's Tale - the TV series. A peak of as high as 148\% was noted only three weeks after its premiere. Also, the victorious Emmy Awards Ceremony (17th September 2017) affected sales, in this case $78 \%$ were added towards the impressive sales' raise. ${ }^{15}$ Both the TV series and its rather positive critical response is therefore beneficial for the popularity of the novel itself. The table below illustrates how each of the three seasons of The Handmaid's Tale were reviewed by Rotten Tomatoes, a review-aggregation website, as well as some critics, therefore giving an example of a possible judgement of what a successful adaptation is.

\begin{tabular}{|l|l|l|l|}
\cline { 2 - 5 } \multicolumn{1}{c|}{} & Release date & Rotten Tomatoes & \multicolumn{1}{c|}{ Critical reviews } \\
\hline Season 1 & $\begin{array}{l}26 \text { th April } \\
2017\end{array}$ & $\begin{array}{l}94 \% \text { critic rating } \\
91 \% \text { audience } \\
\text { rating }\end{array}$ & $\begin{array}{l}\text { "A faithful adaptation of the book that also brings } \\
\text { new layers to Atwood's totalitarian, sexist world of } \\
\text { forced surrogate motherhood". }{ }^{17}\end{array}$ \\
\hline Season 2 & $\begin{array}{l}25 \text { th April } \\
2018\end{array}$ & $\begin{array}{l}89 \% \text { critic rating } \\
80 \% \text { audience } \\
\text { rating }\end{array}$ & $\begin{array}{l}\text { "I have pressed mute and fast forward so often this } \\
\text { season, I am forced to wonder: 'Why am I watch- } \\
\text { ing this'? It all feels so gratuitous, like a beating } \\
\text { that never ends".18 }\end{array}$ \\
\hline Season 3 & $\begin{array}{l}5 \text { th June } \\
2019\end{array}$ & $\begin{array}{l}82 \% \text { critic rating } \\
58 \% \text { audience } \\
\text { rating }\end{array}$ & $\begin{array}{l}\text { "In the third season of the dystopian drama, the } \\
\text { writers are asking us to feel empathy for villainous } \\
\text { characters, a final straw for a show that's already } \\
\text { outstayed its welcome"19 } \\
\text { A. Bernstein, The Guardian }\end{array}$ \\
\hline
\end{tabular}

14 https://www.theguardian.com/books/2017/may/29/the-handmaids-tale-tops-book-charts-after-tv-series-uk-debut (accessed: 20.10.2019).

15 https://www.booknetcanada.ca/blog/2017/10/25/the-handmaids-tale-and-the-emmys (accessed 20.10.2019).

$16 \mathrm{https} / / /$ www.rottentomatoes.com/tv/the_handmaids_tale (accessed 20.10.2019).

$17 \mathrm{https} / /$ www.vulture.com/2017/04/the-handmaids-tale-hulu-review.html (accessed: 20.10.2019).

$18 \mathrm{https}: / /$ www.thecut.com/2018/05/the-handmaids-tale-season-2-review.html (accessed: 20.10.2019).

$19 \mathrm{https}: / / \mathrm{www} \cdot$ theguardian.com/tv-and-radio/2019/jun/05/sympathy-for-the-devil-how-thehandmaids-tale- finally-goes-too-far (accessed: 20.10.2019). 
Adding to this, in order to appeal to a broader audience, the novel adapted onto a silver screen had to be adjusted and reread according to present-day standards. Therefore, when adapting The Handmaid's Tale to 21 st-century requirements and "digital viewers", the details were changed and such pop cultural touchstones as "Uber, Tinder, cappuccinos, and Craigslist in flashbacks to Offred's pre-handmaid life" 20 were added, as Armstrong enlists. On the other hand, the series narrative lacks some of the book's elements, such as the presence of exonowives, who make up the lowest position in the hierarchy and whose presence is made clear by the colour of their uniform (blue, green and grey). The story of Offred's mother (a strong activist in the novel) might serve as another example of a key subplot which has not yet been portrayed in the series adaptation. Nevertheless, the most important factor that changed the perception of The Handmaid's Tale, was the political turmoil in the USA and all over the world. As subsequently noted by Armstrong,

the series felt all the more chilling because of the massive shift in US politics with the election of Donald Trump, who was inaugurated just three months before the series premiered. Suddenly, the book and series' major flashpoints felt more possible than ever: a government declaring martial law after an attack by Islamic extremists, a regime that systematically eliminates gay people, a society that prioritises procreation. ${ }^{21}$

For some time, common consciousness was occupied by the pessimistic vision of the authoritarian tendencies, homophobic and anti-abortion beliefs of Trump's US government. What is more, the cultural awareness of what The Handmaid's Tale was originally about has changed as well. An individual may be relatively distinct from the storyline and future outlook portrayed by the book. This point of view is represented by Glosswitch (a penname of a New Statesman journalist, describing herself as a "feminist mother of three who works in publishing"):

one wouldn't need to have read the novel, nor even have watched the TV show, to know what is meant by everything going "a bit Handmaid's Tale" in Trump's US. References to Gilead can frequently be spotted in feminist protests against the administration's regressive stance on reproductive rights. Atwood's fictional state has come to represent contemporary conservatism, misogyny and religious fundamentalism. "We are being turned into handmaids" is useful political shorthand, a way of saying "we see what you are doing to us - and we've always known you might". 22

Following the undeniable success of The Handmaid's Tale, the sequel, The Testaments was one of the most anticipated books of 2019 (listed by Times ${ }^{23}$ ). Quite predictably, most of the press responses towards the new book of the Can-

${ }^{20} \mathrm{http}: / /$ www.bbc.com/culture/story/20180425-why-the-handmaids-tale-is-so-relevant-today (accessed: 20.10.2019).

${ }^{21}$ Ibid.

$22 \mathrm{https}: /$ www.newstatesman.com/politics/feminism/2018/11/i-loved-handmaid-s-tale-margaret-atwood-s- promise-sequel-makes-me-nervous (accessed: 10.10.2019).

${ }^{23}$ https://time.com/5661400/best-books-fall-2019/ (accessed: 10.10.2019). 
adian writer include a direct comparison to the well-known Handmaid's Tale of 1985. First and foremost, it needs to be stated that waiting 35 years for the sequel encompassed the times of political turmoil and social changes all over the world. Secondly, one should be aware of the fact that the book's reception is to be followed by the existing adaptation of The Handmaid's Tale itself. Hulu and MGM stated to be open and ready to launch a new book-to-series adaptation, based on The Testaments. The President of Television Production, Steve Stark, justified the choice stating that "Margaret Atwood is a literary icon who continues to delight and challenge readers through her provocative and compelling prose" ${ }^{24}$ It is quite interesting to see that these days, writers are willing to collaborate with producers, consequently shaping the script following their own vision. On the one hand, this tendency may contribute to a greater success of an adaptation because the novelist becomes a partner bringing creativity and also resources throughout the production, as Stark admits. ${ }^{25}$ Bruce Miller, TV writer and producer of The Handmaid's Tale, confirmed that he and Atwood collaborated on the TV series script as well as the execution of it for the sake of consistency and cohesion of both the novel and adaptation. On the other hand, Miller states that when Atwood suggested "more restrictions, [...] I gave her more information. I had to be careful about where I was going and what I was doing. She controls the world". ${ }^{26}$ That last sentence may, however, indicate that working alongside the novelist, may disturb the process of interpretation of their literary work and thus limiting artistic vision or even further the audience's reception. There are some doubts of whether collaboration with the novelist affects the outcome of the adaptation by limiting the text's intertextuality. Nonetheless, in the case of The Handmaid's Tale, it proved these questions rather wrong.

To give another example of a successful book-to-series adaptation that corresponds with SVOD's expansion, another of Margaret Atwood's books, Alias Grace, should be briefly noted. Even though both the book and series are set in Canada, written by women and talk about a woman's situation, the geographical and gender factors are not seen as drawbacks or limits. The book was first published in 1996, and as a book-to-series adaptation, it premiered on CBC in September 2017 and later appeared on Netflix in November 2017. In advance of the series' premiere, the first two episodes received a preview screening at the 2017 Toronto International Film Festival in its Primetime line-up of selected television programming. Two book-to-series adaptations of Atwood's fiction launched the same year were inevitably compared to one another. For instance, Lucy Mangan from The Guardian states that

${ }^{24}$ https://www.vanityfair.com/hollywood/2019/09/margaret-atwood-the-testaments-handmaidstale\# (accessed: 5.10.2019).

25 Ibid.

${ }^{26}$ Ibid. 
Perhaps it will be just that bit too "cerebral" to gather as much buzz. But it is quietly just as masterly - an astonishing feat of translation to the screen by writer Sarah Polley [...] and director Mary Harron, and as powerful and subtle a performance from Sarah Gadon as Grace as you could wish. Blessed be this Atwoodian fruit too. ${ }^{27}$

She points out the fact of the novel waiting only 10 years to be turned into a miniseries, in comparison to The Handmaid's Tale that was published in 1985 and adapted into a TV series in 2017. However, New York Times journalist, James Poniewozik clearly states that the successes of the two adaptations should be rather found elsewhere:

That doesn't seem to be the message of the Year of Atwood, with Grace and Handmaid standing like beacons centuries apart. Look back on the calendar, they say, and look forward. The year changes. The time does not. ${ }^{28}$

Alias Grace, not belonging to a dystopian, but historical genre of fiction, concentrates around a young, Irish-Canadian immigrant, a woman who is abused, mistreated and finally silenced sometime in the 19th century. The plot is more akin to a psychological, intimate study of omnipresent problems that we in the $21 \mathrm{st}$ century discuss. Once more, the book-to-series adaptation is launched at the time of Harvey Weinstein's scandal and accusations of his sexual misconduct that consequently affected many women. Most definitely, Alias Grace's success as a book adapted into a series lies in the fact that the topic of the book seems to be rather universal, talks about oppression, suffering, as well as immigration, just as Reilly sees it:

That a centuries-old murder could raise issues of class, gender and power that still resonate today is a testament to Atwood's writing. But its resonance has become so much more acute recently in the midst of a watershed moment wherein hundreds of women (and men) are coming forward daily to share stories of sexual harassment and assault. ${ }^{29}$

The point of reference to a successful production based on a literary prototype is, in the times of SVOD, rather a complex matter. We should look closely at a variety of aspects, starting with adjusting the definition of adaptation to the modern day and therefore accepting new trends in streaming preferences. The timelessness of a book-to-series adaptation often depends on the producers' understanding of contemporary political and social reality and their ability to incorporate this within their version. Based on these two factors, among others mentioned in this text, topicality seems more crucial for the newer types of adaptations rather than plot accuracy. In this view, one may also conclude that the media today need

$27 \mathrm{https}: / / w w w . t h e g u a r d i a n . c o m / t v-a n d-r a d i o / 2017 /$ nov/04/alias-grace-review-margaret-atwood-netflix (accessed: 10.10.2019).

$28 \mathrm{https}$ //www.nytimes.com/2017/11/02/arts/television/alias-grace-review-netflix-margaret-atwood.html (accessed: 10.10.2019).

$29 \mathrm{https}$ //www.rollingstone.com/tv/tv-features/alias-grace-how-a-true-crime-drama-becamethe-most-relevant- show-on-tv-127693/ (accessed: 10.10.2019). 
to constantly undergo the adaptation process themselves to respond to the requirements of the audience alongside production format. Moreover, we must be aware, more than ever before, that thanks to intertextuality, we become both the creators and judges of a book-to-series adaptation.

\section{Seriale na podstawie książek w czasach SVOD - w poszukiwaniu udanych produkcji na przykładach Opowieści podręcznej i Alias Grace Margaret Atwood}

\section{Abstrakt}

Interesującym aspektem tak zwanej kultury masowej jest jej niezwykła zdolność do reagowania na potrzeby społeczeństwa. Podobnie dzieje się w wypadku przemysłu filmowego, który obejmuje wiele dziedzin telekomunikacyjnych, a więc telewizję oraz platformy internetowe do odtwarzania wideo na życzenie (ang. SVOD). To właśnie te ostatnie stają się coraz bardziej popularne, udostępniając bogatą ofertę programową, w tym adaptacje dzieł literackich.

Niniejszy tekst skupia się na analizie zestawu kryteriów używanych do oceny adaptacji filmowych lub serialowych, które powszechnie zalicza się do udanych. Jako przykład służą tu seriale Opowieść podręcznej oraz Alias Grace, dystrybuowane odpowiednio przez Hulu oraz Netflix. Łączy je nie tylko fakt powstania tych seriali na kanwie książek kanadyjskiej autorki Margaret Atwood, lecz także ich popularność wśród widzów, skłonnych do oglądania produkcji intertekstualnych poddających refleksji współczesne normy polityczno-socjologiczne.

Słowa-klucze: adaptacje serialowe, rynek platform streamingowych, intertekstualność, kanadyjskie pisarstwo kobiet, literatura fantastyczna, historie alternatywne

\section{Bibliography}

Books

Albrecht-Crane C., Cutchins D.R., Adaptation Studies: New Approaches, Madison, NJ 2010.

Cartmell D., Whelehan I., The Cambridge Companion to Literature on Screen, Cambridge University Press 2007.

Leich T., Film Adaptation and its Discontents: From Gone with the Wind to The Passion of Christ, Baltimore 2007.

Stam R., Film Theory. An Introduction, Oxford 2002.

Van Parys T., "Against fidelity: Contemporary adaptation studies and the example of novelisation", [in:] Adaptation Theories, ed. J. Saint Jacques, Maastricht 2011. 
http://www.ala.org/advocacy/bbooks/100-most-frequently-challenged-books-1990\%E2\%80\%931999. https://time.com/5059023/most-read-books-2017-amazon/.

https://time.com/5661400/best-books-fall-2019/.

https://www.booknetcanada.ca/blog/2017/10/25/the-handmaids-tale-and-the-emmys.

https://www.merriam-webster.com/dictionary/adapt.

https://www.merriam-webster.com/dictionary/adaptation.

https://www.newstatesman.com/politics/feminism/2018/11/i-loved-handmaid-s-tale-margaret-at-

wood-s-promise-sequel-makes-me-nervous.

https://www.nytimes.com/2017/11/02/arts/television/alias-grace-review-netflix-margaret-atwood.

html.

https://www.rollingstone.com/tv/tv-features/alias-grace-how-a-true-crime-drama-became-the-

most-relevant-show-on-tv-127693/.

https://www.rottentomatoes.com/tv/the_handmaids_tale.

https://www.statista.com/chart/10311/netflix-subscriptions-usa-international/.

https://www.thebookseller.com/news/netflix-buys-50-literary-projects-last-year-988981.

https://www.thecut.com/2018/05/the-handmaids-tale-season-2-review.html.

https://www.theguardian.com/books/2017/may/29/the-handmaids-tale-tops-book-charts-after-tv-

series-uk-debut.

https://www.theguardian.com/tv-and-radio/2017/nov/04/alias-grace-review-margaret-atwood-netflix.

https://www.theguardian.com/tv-and-radio/2019/jun/05/sympathy-for-the-devil-how-the-hand-

maids-tale-finally-goes-too-far.

https://www.theverge.com/2017/2/11/14586382/sales-margaret-atwoods-handmaids-tale-soareddonald-trump.

https://www.vanityfair.com/hollywood/2019/09/margaret-atwood-the-testaments-handmaids-tale\#. https://www.vulture.com/2017/04/the-handmaids-tale-hulu-review.html.

$* * *$

Joanna Szydełko — a PhD student at the Pedagogical University of Kraków, Poland. Her main field of interest is female literature of North America - in both the USA and Canada. Preparing her PhD dissertation, she is focusing on speculative fiction of female Canadian writers from various backgrounds. She has also been researching intersections between women's writings and their film and series adaptations as well as their intertextuality.

Joanna Szydełko - doktorantka Uniwersytetu Pedagogicznego w Krakowie. Jej zainteresowania naukowe obejmują kobiecą literaturę Ameryki Północnej — zarówno w Stanach Zjednoczonych, jak i w Kanadzie. Podczas pracy nad rozprawą doktorską szczególną uwagę poświęca kanadyjskim autorkom piszącym w różnych gatunkach fantastyki (zawierających elementy fikcji alternatywnej i dystopijnej). Dodatkowo w ramach badań naukowych zajmuje się badaniem intertekstualnych związków między literaturą kobiecą a jej adaptacjami. 